\title{
AKATEEMISET MALLIT YRITYSTEN OPPIMISYMPÄRISTÖISSÄ
}

\author{
Toisen maailmansodan aikana syntyi operaatiotutkimuksen nimeä kanta- \\ va tieteenhaara, jossa akateemiset tutkijat kytkeytyivät sotatoimien \\ suunnitteluun. Nyt tällaisia operaatiotutkimusta opetetaan yksin Suomes- \\ sa 14 yliopistossa ja OR-menetelmiä kehitellään palvelemaan yritysten \\ operatiivisten toimintojen optimointia ja strategista päätöksentekoa. \\ Mutta miten nämä kaksi tiedontuottamisen kulttuuria soveltuvat yhteen, \\ yritysmaailma - tai oppivat organisaatiot - toisaalta ja akateeminen \\ maailma toisaalta? Tutkimme yhtä tapausta.
}

\section{STEPHANIE FREEMAN, JOHANNA MOISANDER JA SARI STENFORS}

$\mathrm{N}$ opeatempoisessa, tietoperustaisessa taloudessa aineettoman osaamispääoman tuottaminen on korostunut. Kilpailuetua haetaan yrityksen työntekijöiden ja työyhteisöjen asiantuntemuksesta (intellectual capital) sekä organisaatiokulttuurista ja viestintäjärjestelmistä, jotka tukevat innovatiivisuutta, luovuutta ja organisaation oppimista. Työntekijöiden työssäoppiminen ja organisaatioiden oppiminen ovat siis nousseet entistä keskeisempään asemaan yritysten menestymisen turvaamisessa. Johdon tärkein tehtävä onkin luoda oppimisympäristö, joka tukee ryhmien toimintaa ja innovatiivisuutta ja uuden tietämyksen luomista (Järvinen \& Poikela, 2000).

Tietoyhteiskunnan nykyaikaisissa joustavuutta, dynaamisuutta ja nopeaa reagointia tavoittelevissa organisaatioissa tietotyöläisten päivittäisiä tehtäviä leimaa kuitenkin kiireellisyys ja monimutkaisuus (Helakorpi \& Suonperä, 1995). Ongelmanratkaisutilanteisiin pitää reagoida nopeasti, usein intuition varassa ja niillä resursseilla, joita toimijoilla on kulloisessakin tilanteessa käytössä.

Akateemisessa maailmassa, erityisesti operaatiotutkimuksen (OR, engl. Operations Research tai Management Science) alueella, on kehitelty erilaisia formaaleja matemaattisiin tai loogisiin suhteisiin perustuvia malleja, joilla yritystoimijoita autetaan monimutkaisen ympäristön selvittämisessä, riippuvuussuhteiden hahmottamisessa sekä tulevaisuuden ennustamisessa ja kommunikoinnissa.
Operaatiotutkimuksen perusajatuksena on akateemisten mallien hyväksikäyttö käytännön ongelmissa. Tieteenä OR onkin saanut alkunsa toisen maailmansodan aikana, kun eri tieteenalojen akateemiset tutkijat tulivat sotatoimiin mukaan. Operaatiotutkimuksen menetelmät levisivät nopeasti myös muun yhteiskunnallisen hallinan ja yritysten käyttöön. Suomessa operaatiotutkimusta opetetaan ainakin 14 yliopistossa ja OR-menetelmät ovat käytössä useissa tutkimuslaitoksissa. Alkuaikoina menetelmiä käytettiin lähinnä operatiivisten toimintojen optimointiin, mutta nykyään OR-menetelmiä käytetään myös strategisten päätösten tukena.

Operaatiotutkimuksen ja yritysmaailman välinen yhteistyö ei kuitenkaan ole aina sujunut ongelmitta. Yritysmaailmassa akateemisen tiedon relevanssi on usein kyseenalaistettu, mikä on johtanut siihen, että malleja sekä akateemista tutkimustietoa ei ole aina hyödynnetty yrityksissä (esim. Corner, 2001; Kirby, 2000).

Voidaan kuitenkin väittää, että varsinkin osana uusia tieto- ja viestintätekniikkaan nojautuvia verkostopohjaisia oppimisympäristöjä formaalit mallit voivat auttaa liikkeenjohtoa ja muita asiantuntijoita tuottamaan, rakentelemaan, jakamaan ja välittämään hyödyllistä uutta tietoa sekä yksilöiden että ryhmien suunnittelu- ja päätöksentekoprosessien tueksi. Pelkkä kontekstiin sidottu päättely ei riitä, vaan tarvitaan kykyä nähdä kokonaisuuksia, analysoida ja syntetisoida suuria tietomääriä, ymmärtää laajoja prosesseja ja tehdä yleistyksiä (Tynjälä \& Collin, 2000). 


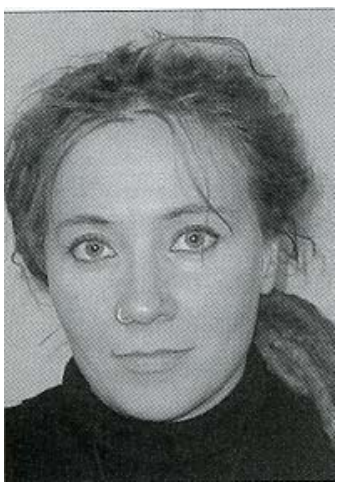

Stephanie Freeman

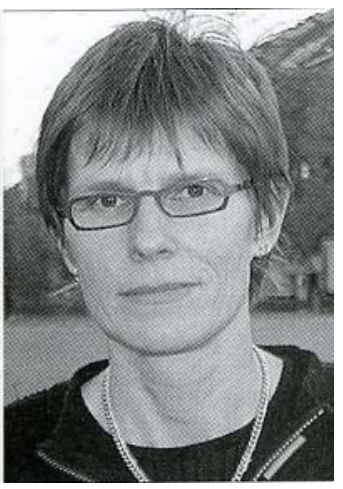

Johanna Moisander

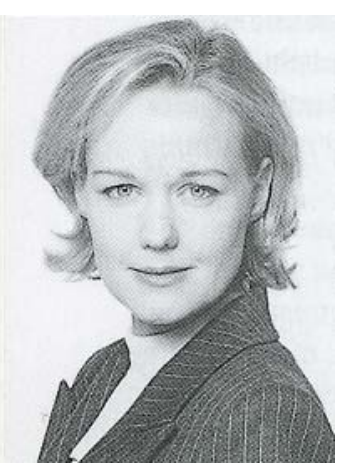

Sari Stenfors
Erityinen haaste perinteisen akateemisen asiantuntijatiedon hyödyntämisessä on se, että työssä oppiminen on nykyisin yhä enemmän luonteeltaan monikontekstuaalista. Nykyaikaiset tietotyöläiset toimivat tiimija verkkopohjaisissa projektiorganisaatioissa. He työskentelevät jatkuvasti monissa yhtäaikaisissa ja rinnakkaisissa projekteissa ja tehtävissä. Tällöin työ tapahtuu "sarjassa paikallisesti jakautuneita toisiinsa liittyneitä osallistumiskehyksiä” (Engeström ym., 1995:15), joissa asiantuntijatiedon ja -taidon kriteerit voivat olla hyvinkin erilaisia.

Voidaankin kysyä, mitä haasteita tällainen työssäoppimisympäristö asettaa akateemiselle koulutukselle, akateemisen asiantuntijatiedon tuotannolle sekä tutkijoiden ja yritysmaailman yhteistyölle. Kuten Tynjälä ja Collin (2000) ovat todenneet, tarvitaan sekä käsitteellistä että empiiristä tutkimusta työhön liittyvistä oppimisprosesseista ja oppimisympäristöistä.

Tarkastelemmekin artikkelissamme formaalien mallien hyödyntämisen mahdollisuuksia ja ehtoja tietoyhteiskunnan "oppivien organisaatioiden" (Senge, 1999; Argyris \& Schön, 1996) haasteellisissa oppimisympäristöissä ${ }^{1}$ ja niihin liittyvissä tiedontuotannon ja -johtamisen käytännöissä.

Tutkimme akateemisten, päätöksenteon tukijärjestelmien kehittäjien ja yrityksessä toimivien käyttäjien yhteistyön mahdollisuuksia ja haasteita tapaustutkimuksen avulla. Hahmotamme, mitä haasteita tietoyhteiskunnan uudet työssäoppimisympäristöt ja niihin liittyvät johtamiskäytännöt asettavat operaatiotutkimukselle sekä akateemisen asiantuntijatiedon tuottamiselle yleensä. Selvitämme, missä määrin perinteiseen tieteelliseen maailmankuvaan perustuvat mallit tukevat näitä uusia tiedontuotannon, työn organisoin- nin ja johtamisen käytäntöjä. Ennen kaikkea pohdimme, minkälaista käsitystä tiedosta ja oppimisesta tällaisten mallien kehittäminen edellyttää.

Artikkelimme jatko koostuu kolmesta pääosasta: tutkimusasetelman ja -menetelmien määrittelystä, tutkimustulosten esittelystä ja johtopäätöksistä.

\section{NÄKÖKULMA, MENETELMÄT JA AINEISTO}

Tutkimuksemme metodologisena näkökulmana on tapaustutkimus (Stake, 1995; Stake, 2000), jonka toteutamme konstruktionistisen tekstinanalyysin menetelmiä (Wetherell, 2001) käyttäen. Käsitteellisenä analyysivälineenä käytämme episteemisen yhteisön ja kulttuurin käsitteitä (Juuti, 1992; Knorr-Cetina, 1999; Longino 2002). Aineistonkeruumenetelminä ovat lähinnä henkilökohtaiset haastattelut ja fokusryhmät.

\section{Tutkimustapaus}

Pyrimme ymmärtämään akateemisen tutkimuksen ja yritysmaailman yhteistyön haasteita ja mahdollisuuksia tiimi- ja verkostopohjaisten oppivien organisaatioiden kontekstissa tutkimalla erään suomalaisen korkeakoulun OR-tutkijoiden sekä erään suomalaisen suuryrityksen välistä orastavaa yhteistyöhanketta. Yritys käyttää korkeakoulututkijoiden rakentamaa päätöksentekomallia strategisessa tiedontuotannossaan mm. tuotteidensa hinnoittelussa ja kilpailija-analyysissä.

Yhteistyön kohteena oleva malli on viimeisimmän akateemisen tiedon mukainen tietokonepohjainen ope-raatiotutkimusmalli (OR-malli). Kyseessä on ns. "black box" -malli, jossa tieto on suljettuna malliin. Informaatioteknologian yleistyessä tällaisia malleja käytetään yrityksissä yhä enemmän ja joskus jopa ilman yrityksen omaa vapaaehtoista ja tietoista päätöstä mallin käyttöönotosta.

Toimintakertomuksensa mukaan tutkimuksemme kohdeyritys pyrkii olemaan dynaaminen ja joustava, verkostoihin perustuva oppiva organisaatio, jonka tavoitteena on yltää huippusuorituksiin ja reagoida nopeasti toimintaympäristössä tapahtuviin muutoksiin.

Tutkimuksemme OR-tutkijat ovat monitavoitteiseen päätöksentekoon erikoistuneita, kansainvälisesti tunnustettuja alansa asiantuntijoita.

Tutkimustapauksenamme on näistä kahdesta 
episteemisestä (tietoa koskevista) yhteisöstä, ORmallin kehittäjistä ja käyttäjistä, muodostuva ihmisryhmä sekä yhteisöjen episteemiset kulttuurit. Ymmärrämme nämä tiettynä kokonaisuutena, tapauksena, ja olemme kiinnostuneita yhteisöjen välisen yhteistyön episteemisistä esteistä ja edellytyksiä. Tarkastelemme näitä yhteisöjä siten myös potentiaalisina yhteistyökumppaneina.

Tapauksen ja siitä kerättävien aineistojen valinnan kriteerinä on ollut teoreettinen kiinnostavuus. OR-tutkijoiden yritysyhteistyötä tarkastelemalla pyrimme ymmärtämään, missä määrin perinteiseen tieteelliseen maailmankuvaan perustuva akateeminen asiantuntijatieto tukee uusia, tietoyhteiskunnalle tyypillisiä tiedontuotannon, työn organisoinnin ja johtamisen käytäntöjä.

Kohdetapauksena OR-tutkimus on tässä yhteydessä erityisen relevantti, sillä OR-tutkimus nojaa perinteiseen, modernin tieteen maailmankuvaan, joka usein kyseenalaistuu tietoyhteiskunnan uusissa johtamiskulttuureissa ja -organisointikäytännöissä.

Akateemisten tutkijoiden ja yritysmaailman yhteistyötä kuvaavana tapauksena tutkimuksemme kohdetapaus ei välttämättä ole mahdollisimman tyypillinen eikä edustava. Se voitaisiin ehkä nähdä jonkinlaisena ääritapauksena, joka poikkeuksellisuudessaan kertoo paljon tutkimastamme ilmiöstä.

Vaikka tutkimusstrategiamme on selkeästi tapaus- ja aineistolähtöinen, analyysi kiinnittyy kuitenkin tiettyihin teoreettisesti rajattuihin, tutkimusprosessin edetessä muotoutuviin mielenkiinnon kohteisiin (episteeminen kulttuuri) ja kysymyksenasetteluihin (episteemiseen kulttuuriin liittyvät diskursiiviset yhteistyön esteet) sekä ohjautuu niiden mukaisesti (Stake, 2000).

Liikkeelle ei ole lähdetty joistakin aikaisempaan tutkimukseen perustuvista, etukäteen määritellyistä teoreettisista propositioista, vaan analysoitavasta tapauksesta. Analyysivälineinä on käytetty teoreettisia käsitteitä. Nämä käsitteelliset analyysityökalut on pyritty valitsemaan siten, että niiden avulla voidaan oppia mahdollisimman paljon tutkimuksen kohteena olevasta tapauksesta ja sitä kautta myös ymmärtää siihen liittyvää tutkimusilmiötä sekä saada vastauksia asetettuihin tutkimuskysymyksiin. Vaikka analyysityökalut on valittu tapauslähtöisesti, ne luonnollisesti kuitenkin heijastavat tutkimusryhmämme jäsenten akateemista taustaa ja omia tutkimusintressejä.

\section{Teoreettinen näkökulma}

Tarkastelemme tutkijoita ja yritystoimijoita episteemisinä yhteisöinä, tutkimme formaaleja malleja ja päätöksenteon tukijärjestelmiä potentiaalisina oppimisvälineinä sekä päätöksentekomallien käyttäjiä potentiaalisina oppijoina.

Akateeminen tutkimus- ja kehitystyö tapahtuu aina tietyssä tutkimuskulttuurissa, jonka julkilausutut ja julkilausumattomat tiedolliset oletukset, tavoitteet ja arvot rakentuvat tuotettavaan tietoon ja joka on siksi tarkasteltava osana tiedon objektia (Harding, 1993; Longino, 2002; Rolin, 2002). Niinpä OR-tutkijayhteisössä vallitsevat malleihin ja mallintamiseen liittyvät, yleensä piiloiset, tiedolliset arvot ja tavoitteet sekä käsitykset mallin kuvaamasta maailmasta tuottavat tietynlaisia tiedontuotannon ja oppimisen ideaaleja, jotka voivat olla enemmän tai vähemmän yhteensopivia yrityksen tietojohtamiseen liittyvien toimintakäytäntöjen ja visioiden kanssa. Siksi analysoimme päätöksentekomallin kehittäjiä ja sen käyttäjiä tietoa tuottavina ja hyödyntävinä yhteisöinä. Tutkimme, minkälaiset tiedolliset (tieteelliset ja/tai professionaaliset) oletukset, tavoitteet, arvot ja käytännöt ohjaavat tiedon tuotantoa ja hyödyntämistä näissä yhteisöissä.

Vertailemme näiden yhteisöjen toimintakulttuureja ja yhteisöllisesti jaettuja todellisuuskäsityksiä (Juuti, 1992) ${ }^{2}$. Analysoimalla eroja yhteisöjen episteemisissä kulttuureissa (esim. KnorrCetina, 1999), erityisesti oppijaan, oppimiseen, oppimisympäristöön ja asiantuntijatiedon kriteereihin liittyvissä käsityksissä, oletuksissa ja odotuksissa, pyrimme tunnistamaan kehittäjien ja käyttäjien välisen vuorovaikutuksen ja yhteistyön esteitä ja edellytyksiä.

\section{Aineisto}

Tutkimusaineisto kerättiin pääasiallisesti henkilökohtaisilla teemahaastatteluilla sekä ryhmäkeskustelulla, joihin osallistui neljä yritysjohtajaa ja kaksi mallien kehittäjä-tutkijaa yliopistosta. Tutkimusaineistoa täydennettiin myös kohdeyrityksestä kertovalla kirjallisella ja online -materiaalilla sekä erillisellä yrityksen kehitysjohtajan vapaamuotoisella haastattelulla. Lisäksi tutustuttiin Suomen Operaatiotutkimusseuran toimintaan.

Tutkimushenkilöitä haastateltiin yksittäin sekä ennen että jälkeen ryhmäkeskustelun. Ryhmäkeskustelussa tavoite oli saada sekä yritystoimijat että mallien kehittäjät puhumaan ja keskustele- 
maan vapaasti yrityksessä tarvittavan tiedon hankinnasta, käytöstä ja saatavuudesta sekä tukijärjestelmien roolista tiedon tuotannossa. Ohjasimme osallistujat keskustelemaan erityisesti myös OR-tutkijoiden rakentamasta mallista, jonka yritys oli ottanut käyttöönsä. Esihaastattelujen sekä kerätyn kirjallisen ja online-dokumenttiaineiston avulla muodostettiin teemoja ja orientoivia kysymyksiä ryhmäkeskusteluun. Loppuhaastatteluilla pyrittiin täsmentämään ryhmäkeskusteluissa saatua tietoa.

Saatu keskustelu- ja haastatteluaineisto nauhoitettiin (fokusryhmä myös videoitiin), purettiin ja litteroitiin tekstiksi, jota analysoitiin tavanomaisin konstruktionistisen tekstianalyysin keinoin (Wetherell et al., 2001). Analyysin kohteena oli tutkijoiden ja yritystoimijoiden puheessa esiintyvät episteemiset lausumat, jotka luokiteltiin neljään episteemiseen kategoriaan. Tutkimme, minkälaisten yhteisöllisesti jaettujen käsitteiden, erotteluiden, ideoiden, metaforien ja argumenttien avulla haastateltavat puhuivat tiedon subjektista, tiedosta sekä sen oikeuttamisesta ja hankinnasta (oppimisesta). Tarkoituksemme oli selvittää, minkälaiset julkilausutut ja julkilausumattomat tiedolliset oletukset, tavoitteet ja arvot jäsentävät OR-tutkijoiden ja yritystoimijoiden tiedontuotantoa ohjaavaa kulttuuria.

Haastatteluilla ja ryhmäkeskustelulla kerättyä tutkimusaineistoa on käytetty aikaisemmin tutkimusryhmämme jäsenen, Stephanie Freemanin pro gradu -tutkimuksessa (Freeman, 2003), josta saatua tietoa on käytetty myös tämän tutkimuksen analyysin tukena.

\section{Tulosten yleistäminen}

Konstruktionistisessa tapaustutkimuksessa keskitytään tutkimaan ilmiön toimintalogiikkaa ja sen muotoutumisprosessia, jolloin ilmiön yleisyys jää vähemmälle huomiolle (Stake, 1995; Stake, 2000). Tutkimuksessamme olemmekin syventyneet siihen, miten ja minkälaisina episteemiset näkemyserot rakentuvat ja esiintyvät - miten esimerkiksi väitetyt akateemiset norsunluutornit rakentuvat jos rakentuvat. Emme niinkään ole kiinnostuneita, kuinka yleisiä tai määrällisesti merkittäviä erot akateemisten tutkijoiden ja yritystoimijoiden episteemisissä kulttuureissa ovat tai miten yleistä on, että akateemisten yhteisöjen ja yritysmaailman episteemiset kulttuurit eivät kohtaa. Tutkimamme tapaus ei siis ole otos jostakin isommasta jou- kosta, eikä sillä pyritä tilastolliseen yleistämiseen.

Kyseessä on pikemminkin analyyttinen yleistäminen. Pyrimme täsmentämään episteemisen kulttuurin käsitettä akateemisten tutkijoiden ja yritysmaailman yhteistyöhankkeen empiirisessä kontekstissa. Tarkoituksemme on esitellä yksi käsitteellistämisen tapa, joka auttaa akateemisen tutkijamaailman ja yritysmaailman yhteistyön esteiden ja edellytysten syvällisemmässä ymmärtämisessä. Tarjoamme siis välineitä analyyttiseen ajatteluun ja kriittiseen keskusteluun (Alasuutari, 1999: 234-237). Nämä käsitteelliset työkalut voivat olla hyödyllisiä myös muissa vastaavanlaisissa konteksteissa ja niillä voi siten olla myös eräänlaista siirrettävyysarvoa.

\section{TIEDONTUOTANNON KULTTUURISIA EROJA}

Tutkimuksemme mukaan akateemiset OR-tutkijat ja nykyisten tiimiorganisaatioiden tietotyöläiset toimivat varsin erilaisissa tiedontuotannon kulttuureissa. Tietoa, oppimista ja yritystoimintaa koskevat yhteisössä jaetut tiedolliset arvot ja normit sekä yleiset todellisuuskäsitykset tuottivat varsin erilaisia kuvauksia ja julkilausuttuja olettamuksia siitä, minkälaista tietoa yrityksessä tarvitaan ja kenen tarpeisiin. Taulukkoon 1 olemme keränneet analyysimme keskeiset tulokset. Haluamme huomauttaa, että kysymyksessä on toimijoiden puhetta ja muuta kirjallista materiaalia analysoimalla muodostettu kuvaus kummassakin episteemisessä yhteisössä vallitsevasta tiedontuotannon kulttuurista sekä siihen liittyvistä todellisuuskäsityksistä. Väitämme, että nämä kulttuurisesti jaetut merkitykset, tiedolliset arvot ja normit, ohjaavat ja rajoittavat sitä, miten kussakin yhteisössä voidaan toimia ja ajatella (esim. Longino, 2002). Artikkelissamme emme kuitenkaan ota kantaa siihen, miten näiden yhteisöjen yksittäiset jäsenet tosiasiallisesti toimivat tai ajattelevat.

\section{Oppija ja oppimisympäristö}

\section{OR-maailma:}

OR-tutkijoiden puheessa tiedon subjekti näyttäytyy muista riippumattomana, itseohjautuvana, rationaalisena yksilönä, jonka episteeminen auktoriteetti perustuu hänen yksilölliseen asiantuntijuutensa sekä tieteellisen menetelmän, formaalin mallin, soveltamiseen. Myös käsitykset oppi- 


\begin{tabular}{|c|c|c|}
\hline $\begin{array}{l}\text { Tiedon alueet } \\
\text { Tiedon subjekti: } \\
\text { käsitys oppijasta } \\
\text { ja oppimis-ympä- } \\
\text { ristöstä }\end{array}$ & $\begin{array}{l}\text { OR-epistemologia } \\
\text { YRITYKSESSÄ: } \\
\text { - Rationaalinen ja itseohjautu- } \\
\text { va päätöksentekijäyksilö (johta- } \\
\text { ja) hierarkisessa organisaatios- } \\
\text { sa. } \\
\text { - Oppijana yksilö. } \\
\text { - Mallit yksilön oppimisen tuki. } \\
\text { OR-MAAILMASSA: } \\
\text { - Rationaalinen ja looginen } \\
\text { asiantuntijayksilö ja hänen me- } \\
\text { netelmänsä. } \\
\text { Oppijana yksilö. }\end{array}$ & $\begin{array}{l}\text { Yritys-epistemologia } \\
\text { YRITYKSESSÄ: } \\
\text { - Yhteisöllinen jäsen tiimi- ja verkosto- } \\
\text { organisaatiossa. } \\
\text { - Tiimi-oppija/ kollaboratiivinen oppija } \\
\text { sekä oppiva organisaatio. } \\
\text { - Mallit osa oppimisympäristöä. } \\
\text { OR-MAAILMASSA: } \\
\text { - Yrityksen yhteistyökumppani ja ”tii- } \\
\text { min jäsen”. } \\
\text { - Tiimi-oppija/ kollaboratiivinen oppija. }\end{array}$ \\
\hline $\begin{array}{l}\text { Tieto: käsitykset } \\
\text { tiedosta ja siitä } \\
\text { mitä voidaan oppia }\end{array}$ & $\begin{array}{l}\text { - Kiistämättömät, yksiselittei- } \\
\text { set, loogiset ja objektiiviset to- } \\
\text { siasiat, jotka voidaan "opettaa” } \\
\text { ja "oppia”. } \\
\text { - Mallit tuottavat edellä kuvat- } \\
\text { tua tietoa. }\end{array}$ & $\begin{array}{l}\text { - Monia näkökulmia ja ratkaisuja sisäl- } \\
\text { täviä, yrityskontekstista kumpuavia ku- } \\
\text { vauksia, ymmärrystä, oivalluksia sekä } \\
\text { muuttuvia tosiasioita. Kritiikki ja ky- } \\
\text { seenalaistaminen olennainen osa. } \\
\text { - Oppimisen kohteena toiminnan kan- } \\
\text { nalta relevantit sosiaalis-materiaaliset } \\
\text { käytännöt. } \\
\text { - Mallit avaavat näkökulmia. }\end{array}$ \\
\hline $\begin{array}{l}\text { Tiedon hankinta: } \\
\text { käsitys oppimis- } \\
\text { prosessista ja op- } \\
\text { pimisvälineistä }\end{array}$ & $\begin{array}{l}\text { - Tietoa rakennetaan tosiasioi- } \\
\text { den pohjalta. } \\
\text { - Päätöksentekijä vertailee te- } \\
\text { hokkaita vaihtoehtoja loogisesti } \\
\text { (usein matemaattisin keinoin) ja } \\
\text { valitsee parhaimman ratkaisun. } \\
\text { - Mallit ovat ratkaisu päätök- } \\
\text { sentekijän ongelmiin, sillä ne ker- } \\
\text { tovat yrityksen todellisesta ti- } \\
\text { lanteesta oleelliseen. } \\
\text { - Mallit ja OR-ihmiset “opetta- } \\
\text { vat” tekemään oikeita ratkaisu- } \\
\text { ja. }\end{array}$ & $\begin{array}{l}\text { - Tietoa hankitaan organisaation sisäi- } \\
\text { sistä prosesseista (mittaukset, haastat- } \\
\text { telut, tiimipalaverit, intranet jne...) sekä } \\
\text { organisaation ulkopuolelta (epäviralli- } \\
\text { set ja viralliset puhelut, e-mail, tapaa- } \\
\text { miset jne...) työnjaollisesti toisiaan täy- } \\
\text { dentäen. } \\
\text { - Päätöksenteko-ongelmat ovat usein } \\
\text { avoimia. Niitä joudutaan muotoilemaan } \\
\text { ja tarkentamaan ”lennossa”. } \\
\text { - Oppiminen on jatkuvaa ja yhteistoi- } \\
\text { minallista. } \\
\text { - Mallit ovat oppimisväline; yksi mui- } \\
\text { den joukossa. }\end{array}$ \\
\hline $\begin{array}{l}\text { Tiedon validointi } \\
\text { ja tietäjän päte- } \\
\text { vyys: tiedon rajat, } \\
\text { tavoitteet ja asian- } \\
\text { tuntijuus }\end{array}$ & $\begin{array}{l}\text { - Hyvä tieto on yleistä, eksak- } \\
\text { tia, usein numeerista. } \\
\text { - Tietoa voidaan siirtää kon- } \\
\text { tekstista toiseen muuttumatto- } \\
\text { mana. } \\
\text { - Päätöksentekijää voidaan aut- } \\
\text { taa tarjoamalla asiantuntija- } \\
\text { apua: päätöksentekijän puut- } \\
\text { teellisia, virheellisiä ja epäloogi- } \\
\text { sia päätelmiä voidaan korjata, } \\
\text { sillä on olemassa oikea ja opti- } \\
\text { maalinen ratkaisu. } \\
\text { - Asiantuntijuus yksilöllistä. }\end{array}$ & $\begin{array}{l}\text { - Hyvä tieto on monipuolista ja kon- } \\
\text { tekstisidonnaista (ottaa huomioon so- } \\
\text { siaaliset, kulttuuriset ja historialliset } \\
\text { käytännöt). } \\
\text { - Tieto on aina rajallista ja suhteellista } \\
\text { eikä ongelma ole aina edes määriteltä- } \\
\text { vissä. } \\
\text { - Päätöksiä pitää tehdä vajavaisin tie- } \\
\text { doin: mielummin huono päätös kuin ei } \\
\text { päätöstä ollenkaan. } \\
\text { - Asiantuntijuus on sidottu työn ku- } \\
\text { vaan ja kontekstiin. Asiantuntijuus yh- } \\
\text { teisöllistä. }\end{array}$ \\
\hline
\end{tabular}


jasta ja oppimisesta ovat siten varsin yksilökeskeisiä.

OR-mallien käyttäjä traditionaalisten OR-kehittäjien käsityksissä on rationaalisuuteen pyrkivä päätöksentekijä, joka työssään vertailee vaihtoehtoja ja valitsee niistä tosiasioiden pohjalta parhaan. Mallin tilaajaa, tarvittavien tietojen antajaa tai päätösvaltaista henkilöä tai henkilöitä kutsutaan kaikkia yleisnimellä "päätöksentekijä”. Usein implisiittisesti oletetaan tämän päätöksentekijän olevan hierarkisessa organisaatiossa toimivan johtajan, jolla on valta ja vastuu organisaation passiivisiksi jäävistä muista jäsenistä.

Mallien käyttöympäristöksi on siis mallia rakennettaessa ajateltu implisiittisesti hierarkinen organisaatio ja sen erilaisista systeemeistä rakentuva maailma. OR-mallien kehittäjien puheessa käsitteet ja todellisuus järjestyvät loogisesti erilaisten toiminnallisten yksikköjen tai komponenttien funktioina. Implisiittisesti tällaisiin reduktionistisiin metodologisiin käytäntöihin näyttäisi liittyvän myös jonkinlainen metafyysinen, ontologinen reduktionismi. Oletetaan tai ainakin toimitaan sen mukaan kuin nämä pienimmät toiminnalliset yksiköt kuvaisivat todellisuutta ja että kausaaliset prosessit voitaisiin viimekädessä ymmärtää näiden pienimpien (havainto)yksikköjen välisinä vaikutussuhteina.

\section{Yritysmaailma:}

Nykyaikaisten yritysten oppimisympäristöissä sen sijaan tiimityö, tiimioppiminen, kollaboratiivinen työ ja kollaboratiivinen oppiminen ovat tulleet oppimisen välineiksi ja yhä tärkeimmiksi työn organisoinnin sekä tietojohtamisen keinoiksi. Kuten tutkimuksemme kohdeyritys, monet aikaansa seuraavat suuryritykset määrittelevät strategiansa ja niitä ohjaavat arvot "elinikäisen oppimisen”, "organisaation oppimisen” ja yhteisöllisen tiedontuotannon käsitteiden ja periaatteiden avulla. Perinteisten hierarkisten linja- ja matriisiorganisaatioiden rinnalle ovat tulleet sekä organisaation sisäiset että organisaation rajat ylittävät tiimit, projektiryhmät, verkostoihin perustuvat solmut sekä näiden erilaiset virtuaaliset muodostelmat (Castells, 1996; Engeström ym., 1999; Tapscott, 1998; Powell, 1990). Näissä organisaatio- ja työympäristöissä suunnittelun ja päätöksenteon yhteisöllisyys, jaettu asiantuntijuus ja jaettu ymmärrys sekä asiantuntijatiedon ja -taitojen kontekstuallisuus korostuu.

OR-mallien kehittäjän odotetaan näissä op- pimisympäristöissä toimivan ikäänkuin tiimin jäsenenä, yhtenä tiimin ja työryhmän monista asiantuntijoista, jotka eivät niinkään ratkaise annettuja ongelmia vaan "kehittävät toimintaa” yritysten strategian ja "visioiden" mukaisesti.

OR-mallien käyttäjä ei myöskään varsinaisesti tee yksin päätöksiä, vaikka voikin ratkaista päätösten tekemiseen liittyviä yksittäisiä ongelmia. Käyttäjät saattavat hyvinkin toimia jatkuvasti monissa yhtäaikaisissa ja rinnakkaisissa projekteissa, tiimeissä ja tehtävissä, joissa työssä tarvittava tieto tuotetaan yhteistoiminnallisesti tiimin jäsenten ja yritysten eri työryhmien välisessä vuorovaikutuksessa kuten seuraavasta haastattelukatkelmasta käy ilmi:

Haastattelija: ...mitä sun työpäivässä tapahtuu?

Yritysjohtaja: ...aika monena päivänä on palavereja puoleen päivään, iltapäivään asti saattaa olla taas semmonen, että... melkein palavereja tahtoo olla joka päivä. Aika harvinaisii päivii on, että on täysin sitä omaa tekemistä varten, että. Sit tietysti päivät menee aika paljon, et keskustelee eri ihmisten kanssa meneillä olevista projekteista ja sit taas oman tiimin jäsenten kanssa, että onhan se tietysti tätä sosiaalista puolta, ett... (1I72T)

Yritystoiminta näyttäisi siis edellyttävän työyhteisön jäseniltä yhteistä ongelmanmäärittelyä, yhteistoiminnallista ongelmanratkaisua ja yhdessä oppimista (ks. Argyris \& Schön, 1996; Senge, 1990; Engeström, 1992).

\section{TIETO JA MALLIEN ROOLI TIEDON JOHTAMISESSA}

\section{OR-maailma:}

No, nyt se mitä, mihin [mallia] voi käyttää, niin sitä voi tietysti käyttää niinkö puhtaasti tähän arviointiin eli arvioidaan sitä, että minkälaista näitten tämmönen ns. tekninen tehokkuus on eli just tässä, et ei oteta mitään kantaa tähän päätöksentekijän mieltymyksiin ja tää on sitä perusideaa. Sitten mitä me on kanssa kehitetty, joissa niinkun yhdistyy tämmönen monitavoitteinen päätöksenteko, jossa tavallaan näitten erilaisten tämmösten outputtekijöiden päälle asetetaan tämmöset preferenssit [...] eli täs on tää yks taso, joka 
tulee lisää. No tämähän on jo sitten heti tämmönen strateginen valinta, että joku ylätason johtaja voi ottaa kantaa siihen, että minkälaiset tavoitteet on tärkeitä, sitä teknistä tehokkuutta. Ja sitten seuraava vaihe siinä on se, että myös voidaan [mallia] käyttää siihen kun suunnitellaan sitä, että kuinka tätä toimintaa voidaan parantaa, jos sä olet tehoton. (Kehittäjä-tutkija 1I68P)

Tieto on OR-tutkijalle yksiselitteisiä ja kiistämättömiä tosiasioita: todennäköisyyksiä, optimointituloksia, oikeita vaihtoehtoja, "sisäänmenosuureita” - lähinnä numeroita. Mallintamista varten tiedon on oltava eksplisiittistä ainakin joiltakin osin. Intuitiota, tunteita, valtaa tai poliittisia aspekteja ei tavallisesti käsitellä tietona. Siksi mallintajat olettavat, että tieto voidaan siirtää kohteesta toiseen sen muuttumatta ja ettei se ole siten riippuvainen henkilöistä tai kontekstista. Ihmisten, päätöksentekijöiden, interaktio mallin kanssa jätetään yleensä tarkastelun ulkopuolelle. Käsitykset tiedosta palvelevat heidän käytössään olevia matemaattisia tai loogisia mallinnustyökaluja. Systeemin kuvaamiseen tarvittava tieto on oltava sellaisessa muodossa, että se on mahdollista mallintaa. Siksi tieto on yleensä jonkin asteisessa kvantitatiivisessa muodossa. ORtutkimuksessa, kuten tieteellisessä tutkimuksessa usein, menetelmillä onkin siten determinoiva eikä alisteinen rooli tiedontuotannossa; ne rajaavat ja muokkaavat ajattelun, teoretisoinnin ja tiedon tilaa sinänsä (Rose, 1996).

Mallit on suunniteltu erilaisten vaihtoehtojen tai odotettujen asiantilojen vertailemiseen. Mallien tehtävänä on kuvata todellisuutta mahdollisimman tarkasti ja objektiivisesti; tiedon on oltava vapaa arkiajattelun epätarkkuuksista ja epäjohdonmukaisuuksista. Ideana on rajata jokin todellisuuden, esimerkiksi liikkeenjohdon strategisen suunnittelun osa-alue ja kuvata siinä esiintyvä ongelma matemaattisena tai loogisena mallina (Bell, 1998). Mallilla etsitään ongelmalle ratkaisu, jonka avulla voidaan löytää paras mahdollinen toimintavaihtoehto vastaavassa käytännön ongelmatilanteessa.

Termillä "näkökulma” viitataan yleensä johdon tavoitteisiin tai laskelmien edunsaajiin, kun toisen voitto on toisen tappio. Muutoin varsinaisesti erilaisia näkemyksiä ei ole, sillä erimielisyydet voidaan selvittää puolueettomien laskelmien avulla. Näin ollen ristiriidat eivät oikeastaan ole aitoja, vaan jokin käsitys tai vaihtoehto on aina virheellinen. Jos eri ryhmillä kuitenkin on erilaisia käsityksiä mallin kuvaamasta järjestelmästä, johtuu se puutteellisesta tietämyksestä, salatuista tavoitteista tai epärationaalisesta ajattelusta.

\section{Yritysmaailma:}

Yritystoimijoiden maailmankäsityksissä taas tieto on kuitenkin vahvasti kontekstuaalista. Tiimija verkostopohjaisissa organisaatioissa OR-mallien käyttäjät joutuvat työssään toimimaan monissa toimintakonteksteissa, jotka vaativat ja tuottavat erilaisia toisiaan täydentäviä mutta myös toisiinsa nähden ristiriitaisia kognitiivisia työvälineitä, sääntöjä ja sosiaalisen vuorovaikutuksen malleja. Näissä eri konteksteissa tiedon ja asiantuntijuuden kriteerit voivat vaihdella suurestikin. Siksi tiedon tuotannossa ja "päätöksenteossa“ on kyettävä sovittelemaan ja yhdistelemään elementtejä eri konteksteista sekä käytettävä monia erilaisia näkökulmia ja dialogisia ongelmanratkaisutapoja (Laitinen, 1996: 89). Aineistossamme mallien käyttäjät kaipailivatkin monia mittareita, joiden avulla asioita voisi tarkastella useammasta näkökulmasta.

Mä näkisin tän [...] mallin niinkun tehokkuuden mittaukseen, niin se voisi olla yksi väline siihen, mun mielestä se pitäis olla, jos aatellaan esim. balancescorecard niin yrityksen niinku toiminnan sisäisen kehittämisen mittauksessa niin mittarin pitäis olla semmonen, et siellä ois useampia niinku näkökulmia, jollakin mittarilla saat jonkun näkökulman ja sit ois niinku toinen mittari, millä sais jonkun toisen näkökulman aikaseksi siitä asiasta, niin silloin niitten yhteissummana vois miettiä sitä mitä vaikutuksia näillä mittareilla on siitä näkökulmasta katsottuna ja toisesta ja mikä niitten kombinaatio on toiminnan kehittämiselle. (Käyttäjä F74L)

Lisäksi tietointensiivisissä yrityksissä työn tekemiseen liittyvät päätöksenteko-ongelmat ovat tyypillisesti avoimia tai vaikeasti hahmotettavia eikä yhtä standardiratkaisua ole olemassa. Monet suunnittelu- ja päätöksenteko-ongelmat on strukturoitava, määriteltävä ja tarkennettava suunnittelu- tai päätöksentekoprosessien kuluessa "lennossa”. Mallin rakentamista ohjaavat "tosiasiat”, tavoitteet, arvot ja tilanteet eivät olekaan pysyviä vaan mallin premissit ovat liikkeessä ja 
tieto muuttuu. Kun samanlaisista lähtökohdista voidaan helposti päätyä monenlaisiin ratkaisuihin, ei päätöksenteko-ongelmia tai prosesseja voida tarkkaan etukäteen määritellä. Eräs yritystoimija totesikin fokusryhmäkeskustelussa, että ”olisi hyvä jos aina olis edes ongelma”.

\section{MITEN TIETOA TUOTETAAN JA MINKÄLAISEEN KÄYTTÖÖN?}

\section{OR-maailma:}

OR-kehittäjä tarjoaa asiantuntija-apuaan päätöksentekijöiden informaation käsittelykyvyn puutteellisuuksien korjaamiseen (esim. Kasanen et al., 2000; Hogarth, 1987). Tämä kävi ilmi fokusryhmähaastattelumme heti ensimmäisessä puheenvuorossa, jossa mallien kehittäjä osoitti harjoitustehtävän avulla, että yritysmaailma ”tarvitsi akateemista apua”, koska johtajat olivat epärationaalisia eivätkä valinneet optimaalista vaihtoehtoa. Pohtiessaan kehittäjien ja yrityksen välisen yhteistyön mahdollisuuksia hän kommentoi yritysedustajien vääriä vastauksia seuraavasti:

Tää esimerkki nyt yleensä vaan tarkottaa, että sitä että on hyvin vaikee tehdä niitä päätöksiä hyvinkin suht simppeliltä näyttävässä probleemassa... Tota, mä oon käyttänyt tätä esimerkkiä yritysjohtajille, kun puhuu niin tää [investointivaihtoehto] on houkutteleva, koska huippujohtajat just tietysti - ei sitä huomaa tuota, että noihin kannattaa sijoittaa. Et sitä helposti pistää tohon ykköseen ja kakkoseen [investointivaihtoehtoja]. No sitten tähän just vois sanoo, että vois tietysti todeta ensinnäkin, että noita formaaleja menetelmiä sitten tarvitaan. Ja jos aatellaan, että minkälaista yrityksien ja korkeakoulujen välinen yhteistyö, niin siitä tietysti vois sanoo, että meiänkin kanssa tehdään nyt jo yhteistyötä. (Kehittäjä-tutkija F52P)

Tiedon ja oikeiden laskentateknologioiden avulla yksilöt oppivat siis suorittamaan heille määrättyjä tehtäviä entistä paremmin, nopeammin ja tehokkaammin. Mallin rakentaja ei yleensä kuitenkaan puutu siihen, miten informaatio mallista muuttuu organisaation tiedoksi. Jotkut nykyaikaiset mallit tosin on suunniteltu käytettäväksi fasilitaattorin läsnäollessa, mutta suurin osa malleista toimii tietokoneen ja käytäjän tai käyttäjien suorana interaktiona.

Mallin kehittäjä ei siis usein ennalta pysty tie- tämään, miten tai mihin mallia todellisuudessa käytetään. OR-kehittäjien näkemys käytöstä perustuukin usein traditionaalisen operaatiotutkimuksen normatiivisiin käsityksiin siitä, kuinka päätökset tulisi tehdä. Ajattelutapaa kuvaa hyvin alan auktoriteetin, Herbert Simonin, kolme päätöksenteon vaihetta, jotka ovat: tietojen keruu, vaihtoehtojen muodostaminen sekä parhaan vaihtoehdon valitseminen (Simon, 1960: 1-8).

Mallien kehittäjien käsityksissä tiedontuotanto nähdään siten helposti prosessina, jossa hierarkisesti järjestyneen organisaation yksittäiset työntekijät suorittavat omia tiedontuotantotehtäviään: keräävät tarvittavia perustietoja tai soveltavat malleja ja määrittelevät erilaisia tehokkaita toimintavaihtoehtoja, joista jokin "ylätason johtaja” sitten valitsee parhaan.

\section{Yritysmaailma:}

Työn tekemisen kannalta tarpeellista informaatiota haetaan eri ihmisten toimesta ja usein yhteistoiminnallisesti erilaisista paikoista: organisaation sisäisistä prosesseista sekä organisaation ulkopuolelta verkostoista. Mallien nähtiin olevan hyödyllisiä siinä, että ne voivat "avata ajatuksia” sekä herättää keskustelua ja kritiikkiä.

Mallien käyttö yrityksessä olikin suurimmaksi osaksi käsitteellistä; vain yksi käyttäjä-johtaja teki mallilla laskelmia (ks. myös Freeman, 2003). Tässä mielessä malli voi toimia potentiaalisena yhteisöllisen oppimisen välineenä: Yksi oppii laskemalla, toinen toisella tavalla, mutta yhdessä opitaan jakamalla jo opittua sekä rakentamalla uutta tietoa. Päätöksenteko on siten yhteistoiminnallista, historiallista, tilannesidonnaista ja jatkuvaa ongelman etsimistä ja määrittelyä.

Eräs käyttäjä-johtaja ilmaisi henkilökohtaisessa haastattelussa, että kyseisen yrityksen tiimiorganisaatiossa "kaikki kuvataan kehämäisinä prosesseina”. Siten myös mallit osana yrityksen oppimisympäristöä ovat jatkuvassa liikkeessä: malleille voidaan määritellä paikka ja mallit voivat osittain määrittää paikan. Tällaista dynaamista ja spiraalimaista tapaa hahmottaa yritystoimintaa pidetäänkin aikuisen oppimisen kannalta tärkeänä (ks. Engeström, 1995).

\section{MIKÄ ON HYVÄÄ TIETOA JA KUKA ON ASIANTUNTIJA?}

OR-maailma:

Traditionaalisen OR-tutkijan käsityksissä hyvä 
tieto on eksaktia ja mahdollisimman virheetöntä, yleensä numeerista tai numeerisessa muodossa esitettävissä olevaa, ja yleistä tai pitkälti kontekstista riippumatonta. OR-mallien kehittäjien puheessa hyvä tieto on lisäksi sellaista, joka kuvaa ilmiötä mekanismeina tai prosesseina, jotka rakentuvat erilaisista mitattavista tai muuten kvantifioitavista komponenteista, joita manipuloimalla näitä ilmiöitä ja niihin liittyvää ympäristöä voidaan hallita. Hyvä tieto voidaankin siirtää kontekstista toiseen muuttumattomana.

Mallintajien on vaikea arvioida mallien käytön vaikutuksia yrityksissä, ja mallien hyvyyttä arvioitaessa he usein kantavat vastuuta ainoastaan mallin teknisestä toiminnasta. Mallinrakentajalle oleellista on mallin validointi eli mm. mallin logiikan tai matematiikan virheettömyys, datan laatu ja oletusten mukainen rakenne. Vastuu mallin käyttämisestä ja mahdollisesta oppimisesta jätetään käytännössä sen käyttäjälle.

Perinteisessä OR-maailmassa käsitykset asiantuntijuudesta ja asiantuntijatiedon kriteereistä perustuvat siten käsityksiin, joiden mukaan asiantuntemuksen mittana on ensisijaisesti yksilön hallinnoiman tiedon määrä ja laatu: OR-kehittäjän asiantuntijuus perustuu erityisesti OR-menetelmien "osaamiseen" ja validien mallien rakentamiseen (myös Pidd, 2001). Mallinrakentajalle on myös luontevaa olettaa, että eri tilanteissa on aina olemassa jokin yksittäinen "paras malli”, kuten seuraavasta esihaastattelukatkelmasta käy ilmi:

Mä luonnehtisin sitä, et se sovellus tai se mihin käytettiin [mallia], niinkun mä alussa sanoin, että mä uskon että me tehtiin paras malli mikä nyt tällä hetkellä kyettiin tekemään ja sitten siinä on tietysti ongelmia, joita pitäis pystyä parantamaan ja se argumentti, mitä mä käyttäisin tässä on tää tieteellisestä realismista oppimani argumentti, että se on olemassa, minkä paras tieteellinen selitys kertoo olevan olemassa eli tavallaan se, että me uskotaan, että ne on tehty niinkun parhaalla tavalla, mutta ei suinkaan täydellistä vaan sitä pitäis niinkun kehittää ja parhaiten siitä saatais kun voitais kehittää muiden [käyttäjien] kanssa. (Kehittäjä-tutkija 1I99P)

Aineistossamme OR-tutkijat esittävätkin itsensä tavallisesti akateemisina konsultteina, ulkopuolisena tiedon lähteenä. Samalla he myös asettavat itsensä tietyssä mielessä yritystoimijoiden yläpuolelle. OR-asiantuntijoiden rakentamat formaa- lit mallit auttavat "oikean ratkaisun” ja "järkevien” valintojen löytämisessä. USA:n OR-tutkijoiden katto-organisaation vuoden 2004 tunnuslause onkin "The Science of Better".

\section{Yritysmaailma:}

Nykyaikaisissa tiimi- ja verkostopohjaisissa oppivissa organisaatioissa on oivallettu, että tietäminen ja osaaminen on luonteeltaan yhteisöllistä (Longino, 2002), ja että asiantuntijuus on oleellisella tavalla sidottu työn kuvaan ja kontekstiin.

Asiantuntijatieto ja sen kriteerit neuvotellaan ja määritellään ihmisten välisessä vuorovaikutuksessa jopa tapauskohtaisesti. Samalla on myös ymmärretty, että tieto on aina rajallista ja ettei selkeitä ongelmia ole aina edes määriteltävissä vaan päätökset on kyettävä tekemään vajavaisin tiedoin: "mielummin huono päätös kuin ei päätöstä ollenkaan”, kuten eräs yritysjohtaja haastattelussa totesi.

Yrityksissä tieto, asiantuntemus ja osaaminen ymmärretään yhä enemmän pitkälti näkökulmaan sidottuina käsitteinä, jotka tuotetaan sekä paikallisissa että kulttuuris-historiallisissa prosesseissa, kuten tämänkin tutkimuksen aineistosta käy ilmi. Ryhmäkeskustelussa yritysedustajat problematisoivat toistuvasti ajatuksen yhdestä oikeasta mallista tai ratkaisusta ja korostivat esimerkiksi, että kaikki OR-mallit ovat aina jostakin näkökulmasta laadittuja: niihin liittyy "poliittisia tavoitteita” ja niillä on monenlaisia aiottuja ja eiaiottuja "ohjausvaikutuksia”, jotka voivat olla negatiivisiakin.

Yritysmaailmassa asiantuntijuudesta ei enää nykyisin puhutakaan yksinomaan pysyvänä yksilön ominaisuutena tai tietovarantona, joka saavutetaan koulutuksen ja oikeiden menetelmien käytön kautta. Asiantuntijuus näyttäytyy pikemminkin sosiaalisena käytäntönä ja oikeina toimintatapoina, joita jatkuvasti määritellään ja uudelleen määritellään yritysten sekä niiden työtekijöiden ja muiden sidosryhmien jokapäiväisessä toiminnassa ja vuorovaikutuksessa. Tällöin hyvän tiedon on oltava "monipuolista" ja tiedon käyttökontekstin sosiaaliset, kulttuuriset ja historialliset käytännöt huomioon ottavaa.

\section{YHTEISTYÖN HAASTEET JA MAHDOLLISUUDET}

Empiirisen tapaustutkimuksemme tulosten perusteella ei ehkä ole kovin yllättävää, että OR-tutki- 
joiden ja yritystoimijoiden välinen yhteistyö on kangerrellut. Erot tiedontuotannon kulttuureissa ovat paikoin hyvinkin merkittäviä. Monissa yhteyksissä yhteinen kieli ja jaettu maailmankuva puuttuu eikä hedelmälliselle yhteistyölle ole suotuisia edellytyksiä. Havainto ei ole uusi; puheet akateemisten tutkijoiden norsunluutorneista ja teoreettisuudesta kuuluvat erottamattomasti keskusteluun yritysten ja korkeakoulujen välisen yhteistyön mahdollisuuksista. Tämän artikkelin ydinajatuksena on kuitenkin ollut pureutua ongelmaan tarkemmin täsmentämällä yhteistyövaikeuksien taustalla vaikuttavia "näkökulmaeroja” tiedontuotantoon liittyvien käsitteiden kautta. Ajatuksenamme on ollut luoda uusia mahdollisuuksia kuilun kaventamiseen yhteisten käsitteiden ja syvemmän ymmärryksen avulla.

$\mathrm{A}$ nalysoimassamme tapauksessa keskeisin yhteistyön este lienee se, että OR-yhteisössä vallitseva tiedontuotannon kulttuuri ei näytä tarjoavan sellaisia todellisuuskäsityksiä tai ajattelun, ymmärtämisen, maailman jäsentämisen ja tulkinnan välineitä, jotka soveltuisivat erityisen hyvin nykyisten tiimi- ja verkostopohjaisten organisaatioiden oppimisympäristöihin ja toiminnan kehittämiseen. OR-tutkijayhteisön episteemistä kulttuuria näyttäisi hallitsevan eräänlainen tekninen asenne ja laskeva-ajattelu (Heidegger 1991; ks. Kakkori, 1998 ja Varto 1991) Maailma käsitetään tieteen ja teknologian avulla hallittavissa olevana objektina, ja todellisuus nähdään muodostuvan olioista ja asioista, jotka voidaan identifioida, mitata, punnita ja muuttaa numeroiksi ja siten ennakoida. Tällaisessa ajattelussa ihminen nähdään helposti vain tilastollisena yksikkönä sekä hallinnan ja manipulaation kohteena (Varto 1991). Erityisen ongelmallista näyttäisi olevan se, että inhimilliselle toiminnalle ominainen sosiaalinen, kulttuurinen, historiallinen ja kontekstuaalinen dimensio jää usein formaalien mallien ja niiden käytön ulkopuolelle.

OR-tutkijoiden ja yritystoimijoiden hedelmällisempi yhteistyö näyttäisi siis edellyttävän jonkinlaista "episteemistä rajankäyntiä”: tiedontuotantoa ohjaavista oletuksista ja normeista keskustelua, neuvottelua ja sovittelua, sekä yhteisen kielen rakentamista ja omien episteemisten alueiden rajavyöhykkeillä toimimista (Galison, 1997; Knorr-Cetina, 1982; Leigh-Starr, 1989).

Selviä vaatimuksia tällaisen rajankäynnin aloittamiseksi onkin OR-tiedeyhteisössä esitetty (esim. Ackoff, 1979; Dando \& Bennett, 1981). Käytännön tasolla tiimiorganisaatioille tyypillisen yhteisöllisen oppimisen ja ryhmäpäätöksenteon ongelmia on yritetty ratkoa kehittämällä laajakatseisempia menetelmiä (esim. Keeney, 1996). Lisäksi on ehdotettu erilaisia näkökulmia kokoavia ja syntetisoivia OR-menetelmiä, jotka perustuvat monien erilaisten, eri tilanteisiin soveltuvien ja eri toimijoiden perspektiivejä edustavien mallien yhteiskäyttöön (Rosenhead \& Mingers, 2001). OR-tutkijoiden ja yritystoimijoiden yhteistyön edellytyksiä on myös pyritty parantamaan kehittämällä uusia eri toimijoiden välistä viestintää helpottavia käytäntöjä ja fasilitointitekniikoita (esim. Levasseur, 1991). Ryhmäpäätöksenteon tukemiseen on noussut jopa oma koulukuntansa operaatiotutkimuksen ja informaatiojärjestelmätieteen yhteistoimintana (esim. Eom et al., 1990).

Kehitysaskeleet ovat kuitenkin olleet yksittäisten pinnalla olevien ongelmien poistamiseksi tarkoitettuja ratkaisuja, eikä epistemologioiden eroavaisuuksia laajemmin huomioiviin ratkaisuihin ole panostettu. OR-tutkijoiden ja yritystoimijoiden yhteistyön kehittäminen edellyttääkin selkeästi yhteisistä lähtökohdista kumpuavaa yhteistyötä ja yhdessä oppimista kehittäjien ja käyttäjien välillä luottamuksen, kommunikaation ja vastavuoroisuuden parantamiseksi.

Yhteistyön onnistumiseksi on kummankin osapuolen tunnettava mallin rajoitteet. Usein blackbox tyyppiset mallit, kuten tutkimamme malli, ovat luonteeltaan byrokraattisia. Ne eivät rohkaise tai tue dialogia ja avointa keskustelua kehittäjien ja käyttäjien välillä vaan saattavat pikemminkin suoranaisesti passivoida työyhteisön toimijoita. Tämä on vaarana etenkin silloin, kun mallin lopullisten käyttäjien rooli ja vaikutusmahdollisuudet mallin kehittelyssä ovat pienet. Tietyn "sisäänkirjoitetun" (Latour \& Woolgar, 1979, 142) ontologiansa ja epistemologiansa kautta, mallit rajoittavat ja suuntaavat toimintaa sekä asioiden esittämistä työyhteisöissä: sitä, mistä puhutaan ja millä tavalla. Mallit avaavat aina tietyn näkökulman ja tavoitetilan, jota tietynlaiset oletukset, arvot ja normit määrittelevät. Siksi mallin käyttö voi olla myös interventio (Wenger, 1998). Malli ei ainoastaan tarjoa optimaalisia toimintavaihtoehtoja tai ratkaisuja päätöksenteon ongelmiin vaan mahdollisesti myös muuttaa niitä prosesseja, joissa nämä ratkaisut ja päätökset tuotetaan.

Näin ollen mallien käyttö saattaa tahattomasti paitsi rajoittaa keskustelua myös lukita tai aina- 
kin pönkittää tietynlaisia valtasuhteita. Henkilöt, jotka ovat osallistuneet mallin kehitystyöhön ja jotka tuntevat siihen sisäänkirjoitetut säännöt ja oletukset, pystyvät hallitsemaan keskustelua paitsi mallista myös sen käyttökohteista ja -konteksteista. Muut jäävät helposti keskustelun ulkopuolelle.

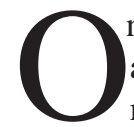
ngelman välttämiseksi käyttäjille tulisi antaa aktiivisempi rooli mallien kehittämistyössä ja heidät tulisi yleisestikin tutustuttaa tarkemmin mallien mahdollisuuksiin ja rajoitteisiin. Mallintajien tulisi puolestaan selventää mallien oletuksia, pohtia mallien räätälöintimahdollisuuksia sekä tutustua paremmin käytännön prosesseihin, joissa käyttötarpeita syntyy ja synnytetään. Akateemiselle OR-tutkimukselle ja tutkijakoulutukselle tämä tarkoittanee sitä, että olisi tarpeellista perehdyttää tulevat ja nykyiset mallinrakentajat laaja-alaisemmin johtamisen ja yritystoiminnan käytäntöihin sekä sitä koskevaan tutkimustietoon. Heidän tulisi tuntea nykyaikaisten yritysten epistemologiaa sekä kasvatustieteellisiin keskusteluihin perustuvia organisaatioja johtamisteorioita, jotka ovat levinneet melko laajalti yritysmaailmassa. OR-tutkijoiden on sekä kyettävä että oltava halukkaita kehittelemään malleja, jotka tukevat epälineaarista ja kehämäistä oppimista, tiimityöskentelyä ja yhteisöllistä oppimista. Ennen kaikkea mallintajien olisi aika ymmärtää, että yksittäisen mallin avulla voi usein tehostaa ainoastaan vain joitain tiettyjä rajattuja työtehtäviä, käytäntöjä ja prosesseja, jotka usein saavat merkityksensä vain yrityksen toiminnan kokonaisuudessa.

Tietoyhteiskunnan uusissa oppimisympäristöissä akateemiselle tiedontuotannolle luonteenomainen yksilöiden kurinalainen ja systemaattinen teoriaan tukeutuva ajattelu ja "sääntöinen oppiminen” (Kolb, 1984) ei siis enää yksin riitä. Malleilla voi hyvinkin olla tärkeä rooli yritysten monimutkaisen toimintaympäristön jäsentämisessä ja hallinnassa sekä työtehtävissä, joissa abstraktin ajattelun, systemaattisen tiedon keräämisen ja loogisen päättelyn tarve on suuri. Mutta osaamispääoman tuotanto, innovointi ja uuden tiedon tuottaminen edellyttävät myös muita oppimisen ulottuvuuksia, mm. generoivaa luovaa ajattelua ja oppimista, jossa vakiintuneet toimintamallit kyseenalaistetaan, sekä tiimioppimista, joka perustuu dialogille ja keskustelulle (Laitinen, 1996).
Olisikin syytä pohtia, miksi tekninen asenne ja laskeva ajattelu edelleenkin jäsentävät niin merkityksellisellä tavalla tutkimamme liike-elämää lähellä olevan, akateemisen tutkijayhteisön episteemistä kulttuuria? Perustuuko tieteellinen auktoriteetti ja tutkijoiden arvovalta edelleenkin lähinnä matemaattisten tai luonnontieteellisten menetelmien käyttöön ja näennäisesti varmojen tosiasioiden tuottamiseen? Kuten artikkelimme toinen nimetön arvioitsija asian ilmaisi, varmuuden myytin korostaminen voi olla hyvä retorinen strategia epävarmuuden keskellä eläville ihmisille.

\section{VIITTEET}

1. Oppimisympäristöllä tarkoitamme tässä jotain fyysistä tai virtuaalista tilaa ja kulttuuria, jossa ihmisillä yhteisöjen jäseninä on käytössään erilaisia teknisiä, materiaalisia, käsitteellisiä, kielellisiä ja sosiaalisia resursseja, joita hyväksi käyttäen on mahdollista oppia: ymmärtää uusia asioita, ratkaista ongelmia ja tuottaa uutta tietoa.

2. Todellisuuskäsityksillä viittaamme tässä työyhteisössä jaettuihin käsityksiin ja merkityksiin, jotka luovat ja ylläpitävät organisaation toimintakulttuuria ja siten myös ohjaavat ja mahdollistavat sen jäsenten havainnointia, arvottamista ja toimintaa organisaatiossa. (Juuti, 1992).

\section{LÄHTEET}

Ackoff, R. (1979). The future of operational research is past. Journal of the Operational Research Society, 30, 93-104.

Alasuutari; p. (1999) Laadullinen tutkimus. Vastapaino.

Argyris, C. \& Schön, D. 1996. Organizational learning II. Theory, Method and Practice. USA: Addison-Wesley.

Bell, P. C. (1999). Management Science/Operations Research: A Strategic Perspective. Cincinnati, Ohio: South-Western College Publishing

Castells, M. (1996). The rise of the network society. Cornwall: Blackwell Publishers Inc

Corner, J. Buchanan, J. \& Henig, M. (2001). Dynamic Decision Problem Structuring. Journal of Multicriteria Decision Analysis, 10, 129141.

Dando, M.R., Bennett, P.G. (1981). A Kuhnian Crisis in Management Science? Journal of 
the Operational Research Society, 32, 91-103.

Engeström, Y. (1992). Interactive expertise: studies in distributed working intelligence. Research bulletin; 83. Kasvatustieteiden laitos. Helsingin Yliopisto.

Engeström, Y. (1995). Kehittävä työntutkimus. Perusteita, tuloksia ja haasteita. Helsinki: Painatuskeskus OY.

Engeström, Y., Engeström, R. \& Kärkkäinen, M. (1995). Oppiminen ja Ongelmanratkaisu monimutkaisissa työprosesseissa. Aikuiskasvatus 1/1995, 13-27.

Engeström, Y., Engeström, R. \& Vähäaho, T. (1999). When The Center Does Not Hold: The Importance Of Knotworking. Chaiklin, S., Heidegaard, M. \& Jensen, U.J. (Toim.) Activity Theory and Social Practice: CulturalHistorical Approaches. Aarhus University Press.

Eom, H., Lee, S. \& Suh E.-H. (1990), Group Decision Support Systems: An Essential Tool for Resolving Organizational Conflicts. International Journal of Information management, 10, 215-227.

Freeman, S. (2003). Mystery of the Black Box: The Case of the DEA-model in a Finnish Electricity Distribution Company. Aikuiskasvatustieteen Pro Gradu tutkielma. Kasvatustieteen laitoksen kirjasto. Käyttäytymistieteellinen tiedekunta.

Galison, P. (1997). Image and Logic. A Material Culture of Microphysics. Chicago and London: The University of Chicago Press.

Harding, S. (1993). Rethinking Standpoint epistemology: What is 'Strong Objectivity'?, teoksessa Alcoff, L, and E. Potter (toim.) Feminist Epistemologies, New York: Routledge, 49-82.

Heidegger, M. (1991) Silleen jättäminen. Filosofisia tutkimuksia Tampereeen Yliopistosta XIX.

Helakorpi, S. \& Suonperä, M. (1995). Laatuajattelua uuteen oppimisympäristöön, Aikuiskasvatus, 1/1995, 4-10.

Hogarth, R. (1987). Judgment and Choice, $2^{\text {nd }}$ edition, Chichester: Wiley \& Sons.

Juuti, P. (1992). Viimeaikaisia näkökulmia organisaation kehittämisestä, Aikuiskasvatus 1/99, 23-36.
Järvinen, A., Poikela, E. (2000). Työssä oppimisen reflektiivisyys ja kontekstuaalisuus. Aikuiskasvatus 4/2000, 316-324.

Kakkori, L. (1998) Martin Heideggerin maailma. Teoksessa: Kuhmonen, P. \& Sillman, S. (toim.) Jaettu jana, ääretön raja: Pellervo Oksalan juhlakirja. Jyväskylän yliopiston filosofian julkaisuja. (saatavilla http:// www.cc.jyu.fi/ lkakkori/peltsi.html, 20.8.2004)

Kasanen, E., Wallenius, H., Wallenius, J. \& Zionts, S. (2000). A study of high-level managerial decision processes, with implications for MCDM research. European Journal of Operational Research, 120, 296-510.

Keeney, R .L. (1996). Value-Focused Thinking: A Path to Creative Decisionmaking, Harward University Press.

Kirby, M. (2000). Operations research trajectories: the Anglo-American experience from the 1940s to the 1990s. Operations Research, 48(5), 661-670.

Knorr-Cetina, K. (1999). Epistemic cultures. MIT Press.

Knorr-Cetina, K. (1982). Scientific communities or Transepistemic Arenas of Research? A Critique of Quasi-Economic Models of Science. Social Studies of Science, 12, 101130.

Kolb, D. A. (1984). Experiential Learning: experience as a source of learning and development, Englewood Cliffs: Prentice Hall.

Laitinen, R. (1996). Oppivaa organisaatiota etsimässä. Aikuiskasvatus 2/1996.

Latour, B., Woolgar, S. (1979). Laboratory Life: The Social Construction of Scientific Facts. Beverly Hills: Sage.

Leigh-Starr, S. (1989). The structure of Ill-structured Solutions: Boundary objects and Heterogeneous Distributed Problem Solving. Teoksessa Gasser, L., \& Huhns, M. (toim.) Distributed Artificial Intelligence. Vol. 2. London: Pittman.

Levasseur, R. E. (1991). People Skills: Effective Communication - A Critical Skill for MS/OR Professionals," Interfaces, 21 (2), 22-24.

Longino, H. (2002). The Fate of Knowledge. Pinceton and Oxford: Princeton University Press. 
Pidd, M. (1999). Just modeling through: A rough guide to modeling. Interfaces, 29 (2), 118-132.

Powell, W. W. (1990). Neither Market nor Hierarchy. Network Forms of Organization. Research in Organizational Behavior, 12, 295336.

Rolin, K. 2002. Tieteen etiikka metodologian näkökulmasta. Teoksessa Karjalainen, S \& V. Launis, R. Pelkonen ja J. Pietarinen (toim.) Tutkijan eettiset valinnat, Helsinki: Gaudeamus, 92-104.

Rose, N. (1996). Power and Subjectivity: Critical History and Psychology. Teoksesssa F. Graumann and K. J. Gergen, (eds.), Historical Dimensions of Psychological Discourse, Cambridge University Press.

Rosenhead, J. \& Mingers, J. (2001). Rational Analysis for a Problematic World Revisited, Chichester: Wiley.

Senge, P. (1999). The Fifth Discipline. London: Doubleday.

Simon, H. A. (1955). A behavioral model of rational choice. Quarterly Journal of Economics, 69, 99-118.

Simon, H. A. 1960. The New Science of Management Decision. New York: Harper \& Row.
Stake, R. (1995) The Art of Case Study Research. London: Sage.

Stake, R. (2000) Case Studies. Teoksessa Denzin, N. \& Lincoln, Y. (toim.) Handbook of Qualitative Research. London: Sage, 435454.

Tapscott, D. (1998). The Digital Economy. Promise and peril in the age of the networked intelligence. New York: R.R. Donnelley \& Sons.

Tynjälä, P. \& Collin, K. (2000). Koulutuksen ja työelämän yhteistyö - pedagogisia näkökulmia. Aikuiskasvatus 4/2000, 293-305.

Varto, J. (1991) Nuoruuden viisaus. Kirjeitä perusasiasta. Filosofisia tutkimuksia Tampereen yliopistosta XV. Tampere.

Wenger, E. (1998). Communities of practice. Learning, meaning and identity. New York: Cambridge University Press

Wetherell, M., Taylor, S. \& Yates, J.S [toim.] (2001). Discourse as Data, London: Sage.

Artikkelissa raportoitu tutkimus on tehty osin Liikesivistysrahaston myöntämän apurahan turvin.

Artikkeli saapui toimitukseen 14.4.2004. Se hyväksyttiin julkaistavaksi 11.8.2004. 